\title{
The Iron Ore Supplies of the World.
}

\author{
By F. H. НатсH, M.Inst.C.E., Past-President Inst. Min. Met.
}

The following article originally appeared in the special "Iron and Steel" number of the Times Trade Supplement on July 21 last. It is here reprinted, with some small additions, by the courtesy of the proprietors of that journal.

$W^{\text {ITHIN the limits of a brief article such as this must necessarily }}$ be, it is impossible to do more than indicate the chief sources of iron-ore supply. The subject is a big one, and of great importance, not only to the British ironmaster, but also to every inhabitant of this country. I am therefore pleased to be able to state that the Federation of Iron and Steel Manufacturers has not only asked the Imperial Mineral Resources Bureau to prepare a summary of the existing information as to the iron-ore supplies of the world, but is also assisting to finance the inquiry. This will mean a more complete survey than is possible to-day.

Any attempt to estimate the world's iron-ore resources is complicated both by the diversity of the products manufactured from the raw material and by the numerous factors which go to connote a commercial iron-ore. Among these the iron content, the presence of beneficial or deleterious constituents, physical condition, geographical position, and means of transportation are all considerations of the first importance.

First consider the iron-content. According to the estimate of the American geologist, Clarke, the crust of the earth contains 4.4 per cent of metallic iron, of which but a very minute fraction has been sufficiently concentrated by geological agencies to form commercially available iron-ores : for one ton of these that contains 60 per cent of iron there are very many tons that contain 50 per cent; while for one ton that contains 40 per cent there are vastly more that contain 30 per cent, and so on. The amount of reserves in an ironore field can, therefore, be indefinitely increased by lowering the grade of the material to be included.

With regard to the presence of beneficial or of deleterious constituents, what is prejudicial in one case is beneficial in another. The requirements of the smelters are decisive on this head. If hæmatite pig iron for the acid process of steel-making is required, phosphorus is barred; if, on the other hand, the iron is destined for the basic process, phosphorus is a desideratum. Titanium rules out vast bodies of ore containing a high percentage of iron, because the presence of titanic acid in any notable proportion raises the temperature of fusion and leads to greater fuel consumption and a heavier blast. A small quantity of manganese, on the other hand, is beneficial, since it helps to get rid of sulphur. A high silicacontent is an objection, because of the limestone that has to be added to the charge to neutralize the acid constituent, thereby reducing the output per furnace and increasing the cost per ton of pig; but a calcareous ore is sought after, since it is either self-fluxing or can, 
if the lime is present in excess, be mixed with siliceous ores in the proportion required for a fusible charge. A self-fluxing ore containing 25 per cent of iron may be as valuable as, or even more valuable than, a refractory ore containing 35 or 40 per cent. Therein lies the virtue of the calcareous ores of Frodingham in North Lincolnshire.

The physical condition of the ore is of the highest importance. If the ore is friable, disintegrates during transportation, and arrives at the smelting works in a dusty condition, or "decrepitates" when heated, it chokes the furnace, prevents the free passage of the gases, and leads to dust losses. Although friable ores can be improved by sintering or nodulizing, this can only be done at the expense of a heavy increase in the cost of production. On the other hand, a hard, dense ore, such as certain classes of magnetite, is refractory, and consequently not looked upon with favour by the ironmaster, except for enriching purposes.

The position of an iron-ore field in regard to the smelting centre has the greatest influence of the utility of the ore. An ore may be desirable in all other respects, but inaccessibility may prevent its use. A notorious case is Brazil, where vast deposits of the best class of iron-ores remain unworked because of their unfavourable geographical position.

The first attempt at a census of the iron-ore resources of the world was an inquiry made upon the initiative of the Executive Committee of the International Geological Congress, which met in Stockholm in 1910, and based on the returns obtained from official and non-official geologists all over the world. A summary of the returns from the five continents made by $H$. Sjogren showed that the actual known reserves of the world amounted to 22,400 million tons, of which the equivalent iron was estimated to be just over 10,000 million tons, or, at the then rate of pig-iron production of 60 million tons per annum, insufficient to last for 200 years, without allowing for any increase in consumption. Since 1910 the extension of knowledge by exploratory and development work has led to repeated revisions of Sjögren's figures.

The principal known iron-ore reserves of the world are those of the Eastern United States, Newfoundland, Cuba, Brazil, Lapland, Spain and the north coast of Africa, the Central European orefield, and the United Kingdom. There are probably also considerable reserves in India, South Africa, Australia, and Canada.

\section{UNITED KINGDOM.}

Of the 15 million tons of iron-ore produced in 1918 in the United Kingdom, 80 per cent consisted of Jurassic ironstones, 10 per cent of West Coast low-phosphorus hæmatite, 8 per cent, of Coal Measure ironstone, and 2 per cent came from miscellaneous sources.

An estimate of reserves was made by the Geological Survey in 1917. Taking the Jurassic ironstones first, the following are the tonnages arrived at for "reserves partially developed", under the 
headings of ore to be got (1) by open-cast work and (2) by underground mining, from which I have made a deduction for the ore won during the years 1917-19.

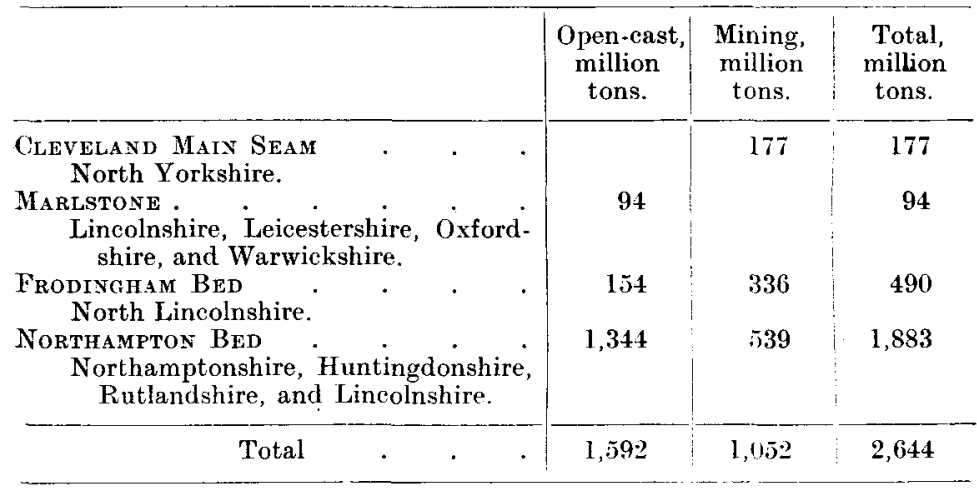

In addition, 26 million tons are assigned to the Westbury (Corallian) ironstone, and 10 million to the Raasay ironstone, neither of which are at present being worked as a source of iron. This brings the total for the Jurassic ironstones to 2,680 million. It is not claimed that these figures are estimates of actually merchantable ore. It is possible that much of the low-grade ore that it is now found profitable to work in open quarries will not constitute an economic proposition when mining has to be resorted to.

The reserves of clay-ironstones and blackband ironstones in the Carboniferous strata of England and Wales are estimated by the Survey at 1,057 million tons. The Scotch Coalfields are estimated to have a reserve of 93 million tons of ironstone, making 1,150 million tons in all. Much is included that in all probability will never be mined. The richer and thicker seams of blackband have long since been worked out, and the present output comes mainly from North Staffordshire and Scotland. In 1918 out of a total output of $1,120,000$ tons of Coal Measure ironstone, 1,052,000 tons came from those districts. The clay-ironstones, too. are not worked systematically except in a few places; in many collieries the clayband ribs are only taken down in "brushing" the roads, and in the case of a ball-ironstone the balls are put aside as they occur during the working of the coal, or fireclay, as the case may be, and marketed when a sufficient quantity has accumulated. The output of Coal Measure ironstone, which amounted to over 6 million tons per annum in the 'seventies, has been falling for many years, and is now little over a million tons per annum. The Director of the Survey, in an introduction to the Memoir on the Carboniferous Bedded Ores, states his belief that under present conditions only about half the amount estimated would be available, and in the Memoir dealing with the iron-ores of Scotland a 30 per cent deduction 
for losses in mining is suggested. For the present purpose a round 50 per cent of the total given for areas partially developed is taken, which brings the total reserves for Coal Measure ironstone down to 575 million tons of ore of about 30 per cent grade.

In all, therefore, the low-grade ores of the United Kingdom are estimated at 3,219 million, or, say, in round figures 3,000 million tons of 30 per cent ore.

The reserves of low-phosphorus hæmatite of Cumberland and Lancashire are estimated by the Survey at 40 million tons. The grade may be taken at 50 per cent.

\section{Spain and North Africa.}

Spain has in the past been the principal source of supply for the high-grade low-phosphorus ores used in European furnaces. The production reached 10 million tons in 1913 ; but it fell to about half that amount during the War. For many years British makers of hæmatite pig for Bessemer and Siemens Martin steelworks have derived the greater proportion of their ores from Bilbao (some $2 \frac{1}{2}$ million tons per annum); but three-quarters of the workable ore has already been mined, and for some time there has been a gradual deterioration in quality due to the exhaustion of the richer mines.

The low-phosphorus ores of Bilbao consist of rena, campanil, rubio (all three varieties of hæmatite), and spathic (the carbonate); but the qualities now exported are practically confined to "rubio" and calcined "spathic". The standard guarantee for "best rubio" is 50 per cent iron, 8 per cent silica, and under 02 phosphorus, but many shipments run about 47 per cent iron, 10 per cent silica, and -025 phosphorus. The guarantee for "best calcined spathic" is 56 per cent iron, but on account of fuel scarcity cargoes of about. $54 \frac{1}{2}$ per cent iron and $9 \frac{1}{2}$ per cent silica are delivered. Among other ores imported are the Santander washed granular ores, but these, being higher in phosphorus, can only be used in combination with a considerable proportion of other purer ores. Rubio ore is also worked at Castro (Dicido) in Santander, and considerable reserves of low-phosphorus and low-silica ore with iron 47 per cent exist in Almeria (Alquife). A large quantity of ore is mined in Seville and Teruel (Sagunto). Deposits of hæmatite, magnetite, brown ore, and carbonate are also known in the following provinces: Guipuzcoa, Oviedo, Leon, Lugo, Malaga, and Granada; but they have not been much developed and the extent to which they will be worked in the future depends on the results of investigation and the provision of adequate transport facilities. Few of the ores are equal in quality to those of Bilbao.

The Stockholm estimate for the actual reserves of Spain, brought up to date by the Imperial Mining Resources Bureau, is 650 million tons, of which 28 million is credited to Bilbao.

High-grade ores (averaging about 50 per cent iron) are found on 
the north coast of Africa in various parts of the Atlas Mountains in Algeria, Tunis, and Morocco ; in large part they are of Bessemer grade. The production of these fields amounted in 1913 to close on 2 million tons, of which three-quarters of a million went to England. The principal producers are Benisaf, Zaccar, and Timezrit in Algeria, Djerissa in Tunis, and Riff in Morocco. It is estimated that the output can be increased by half a million tons or more a year by completing the railway from the port of Bona to the Ouenza and Bou Kadra mines, which are in Algeria near the Tunisian border, and about 120 kilometres from the coast. The reserves for North Africa have been estimated at from 100 to 150 million tons.

\section{Scandinavia.}

Swedish iron has long been celebrated for its purity and general excellence. The low-phosphorus ore used in its manufacture is in the main magnetite, and comes from a number of old mines in southern Sweden, among which may be mentioned the celebrated Dannemora and Persberg mines. It is smelted locally with charcoal and the reserves are comparatively small. In central Sweden there are some large hæmatite deposits, as, for example, those of Grängesberg and Norberg, which yield ore averaging 60 per cent iron and high in phosphorus. The reserves are estimated at about 100 million tons.

The main resources of Sweden are in Lappland. Great deposits of iron-ore occur there, mainly magnetite and, as a rule, high in phosphorus, although a trifling proportion is of acid Bessemer grade. The largest and most celebrated ore bodies are those of Kiirunavaara and Gellivare, the former (together with Luossavaara) being credited with a reserve of 738 million tons, and the latter (including Kokullskulle) with 265 million. Both orebodies were formerly worked on the open-cast system, but underground mining has recently been substituted at Gellivare. They are owned by the Trafikaktiebolag Grängesberg-Oxelösund of Stockholm, and the ores are sold by this Company on a basis of 60 per cent iron, as received, the following grades being distinguished by the phosphorus content :-

\begin{tabular}{c|l}
\hline Grade. & \multicolumn{1}{|c}{ Phosphorus, per cent. } \\
\hline $\mathrm{C}^{1}$ & $\begin{array}{l}\text { Not more than } 06 . \\
\mathrm{C}^{2}\end{array}$ \\
$\mathrm{D}$ & $\begin{array}{l}\text { Not more than } 1 \cdot 0 . \\
\text { Over } 10 \text { and not more than } 2.0 . \\
\text { Over } 2 \cdot 0 .\end{array}$ \\
\hline
\end{tabular}

The output is limited by law to $1,300,000$ tons per annum for Gellivare, and 5 million per annum for Kiruna.

The shipping ports are Narvik, on the Atlantic coast, and Lulea, on the Baltic. The former is open all the year round. Before the War 
80 per cent of the output went to Germany, but in 1916 a contract was made with the Swedish Government which secured for the United Kingdom approximately 50 per cent of the output.

In Norway the deposits, although large, are of low grade, and require concentration. The present production is small. The most important is that at Sydvaranger, on the northern coast, the shipping port, Kirkenes, on the south side of Varanger Fjord, being within the Arctic Circle. The ore is a low-phosphorus magnetite, occurring in close association with apatite and interbedded with quartz. The bulk of it averages from 30 to 35 per cent iron, and is worked open-cast; but a smaller quantity of 50 per cent ore is mined. To free the ore from apatite a magnetic concentration plant is used, yielding a product which, when briquetted, contains 65 per cent iron and 02 phosphorus. The reserves are estimated at 100 million tons raw ore. At Dunderland, on the west coast, there is a large deposit of mixed hæmatite and magnetite in association with apatite, the raw ore averaging about 35 per cent iron with a high phosphorus content. By special methods of concentration it is stated that the magnetite and hæmatite can be separated, and the grade of the ore brought up to 68 per cent iron, with only 03 per cent phosphorus. The reserves are estimated at 150 million tons.

The estimate of the Scandinavian reserves as a whole made by the Swedish geologists for the Stockholm Report, but as revised and brought up to date by the Imperial Mineral Resources Bureau, is as follows:-

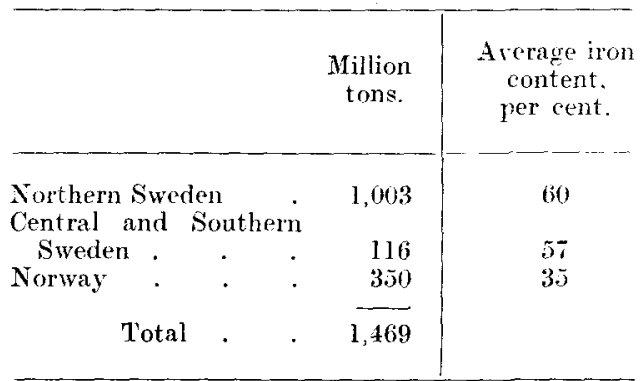

Say, 1,500 million tons of 54 per cent grade.

Central Europe.

The "minette" orefield, which extends over a portion of AlsaceLorraine, Luxemburg, and Belgium, is the most important, in regard to quantity, in Europe, and the struggle for its possession was one of the main causes of the late War. The annexation in 1871 of the eastern part of the field gave Germany the means of building up a great iron trade, while the early occupation of the Briey and Longwy basins proved a severe handicap to France during the progress of the War. This field in 1912 produced 44 million tons or 28 per cent of the world's output, divided between Germany, Luxemburg, and 
France. The ore-geologically a bedded oolitic ironstone of Jurassic age - is a carbonate, partly oxidized to brown ore, containing from 27 to 36 per cent iron, as mined, with an average of 10 per cent moisture. The ores are in part siliceous, in part calcareous, and good smelting charges can be obtained by mixing these two varieties in suitable proportions. A valuable feature is the high-phosphorus content, permitting the manufacture of a basic pig containing from 1.7 to 1.9 per cent phosphorus, and suitable for the basic Bessemer or Thomas process. In the greater portion of the field only one bed (the "grey bed") is worked; but its thickness varies from 6 to 20 feet and the reserves are very large, being generally put down at about 5,000 million tons.

Besides the minette ores, France possesses in Normandy, Anjou, and Brittany, oolitic bedded ores of Ordovician age. These occur in a number of detached synclines either as carbonate or hæmatite. The ores (calcined in the case of the carbonate) average from 45 to 48 per cent iron, 10 to 20 per cent silica, and 0.4 to 0.8 per cent phosphorus. They are smelted to basic iron at the Mondeville works, near Caen, for the Normandy deposits, and at the Trignac works, near St. Nazaire, for the Brittany and Anjou deposits. The reserves are estimated to be about 200 million tons.

With the cession of Alsace-Lorraine, Germany lost its biggest orefield, but it retains a number of smaller producing districts, the reserves of which amount to some 1,300 million tons.

\section{United States.}

Lake Superior produces four-fifths of the iron-ore output of the United States. (In 1918 it was 86 per cent of a total of 70 million tons.) The ore is derived from a series of ranges in Minnesota, Wisconsin, and Michigan, respectively known as the Mesabi, the Marquette, the Menominee, the Gogebic, the Vermilion, and the Cuyuna, the order given being that of the importance of the annual production. At first all the ore was obtained from open-workings by steam-shovel and other forms of mechanical excavator, and was shipped without further treatment. Mining is, however, becoming more and more necessary, and in places water-concentration, and even calcining, are being introduced in order to raise the iron content and diminish the silica and sulphur. The ore is in the main a hæmatite, but in part is hydrated. Magnetite is only found in the Marquette range and in small proportion. The average iron content of the ore mined is diminishing, having fallen from 56.2 per cent in 1902 to 52 per cent in 1912. The phosphorus content, too, is increasing, the percentage of Bessemer ore having fallen from 64.9 in 1902 to $42 \cdot 9$ in 1912 .

From the iron ranges the ore is railed to the shipping ports of Duluth, Ashland, Marquette, and other ports at the western end of Lake Superior, and from there shipped by water to be smelted in Chicago, on the shore of Lake Michigan, or at Cleveland and Buffalo 
on Lake Erie. The bulk of it, however, is passed on by rail to Pittsburg and other industrial centres of Pennsylvania and Ohio, the total distance by water and rail to Pittsburg being about 1,200 miles, and thus greater than that of the iron mines of Spain and Scandinavia from British or German furnaces. Cheap water transportation on the Great Lakes has made this possible. The oreships are loaded direct from the ore-trains at the rate of 10,000 tons in half an hour, and discharged at the receiving dock in less than half a day. In 1913 the rate for water transport and unloading averaged less than 07 of a cent, or (at normal exchange) 035 of a penny per ton-mile. Although navigation is closed for about five months in the year, and a stock pile of 25 million tons has to be accumulated at the loading end, over 60 million tons a year are conveyed in this manner, and by the end of 1918 the Lake District had marketed no less than 900 million tons of ore.

A recent estimate of the available reserves at Lake Superior is 2,750 million tons of an average grade of 52 per cent iron (Mineral Industry, 1918).

The red or Clinton hæmatites are bedded oolitic ores of Silurian age cropping out on the eastern flank of the coalfield-from Maryland through Virginia and Tennessee to Georgia and Alabama. They reach their highest economic development in the Birmingham district of Alabama, although they are also worked in Georgia and Tennessee, and to a small extent in Virginia. Although the Clinton ores as a whole are rather high in silica, this is to a considerable extent offset by the presence of a good proportion of lime carbonate. Including the Brown Ores worked in the Appalachian Valley and in Tennessee, these south-eastern states had, up to 1918 , produced 10 per cent of the whole iron-ore output of the United States. The available reserves are estimated at 1,750 million tons of 36 per cent grade phosphoric ore.

The north-eastern states (New York and New Jersey and Pennsylvania), contribute 1 per cent of the total iron-ore output of the United States. The ores are derived from magnetite mines in the Adirondack region of New York, from Clinton ores in Pennsylvania, and from Brown Ore in Northern New Jersey. In the main they are phosphoric ore, and are used locally. The undeveloped reserves, with an average grade of 35 per cent iron, are estimated at 2,500 million tons.

The following table gives in parallel columns the most recent estimates and those made for the Stockholm Geological Congress :-

Stockholm.

$\begin{array}{llc} & & \text { Million tons. } \\ \text { Lake Superior } & : & 3,500 \\ \text { Clinton Ores } & : & 505 \cdot 3 \\ \text { Miscellaneous } & \cdot & 252 \cdot 5 \\ & & \\ 4,257 \cdot 8\end{array}$

Recent Estimates. (Mineral Industry, 1918.)

$\begin{array}{lc} & \text { Million tons. } \\ \text { Lake Superior } & 2,750 \\ \text { S.E. States (Clinton, etc.) } & 1,750 \\ \text { N.E. States } \quad \cdot \quad \frac{2,500}{7,000} & \end{array}$


It will be seen that in comparison with recent estimates, the Stockholm report over-estimated the Lake Superior area, but did not attribute sufficient importance to the remaining areas. Neither estimate includes any of the very low-grade red or Clinton ores, or of the low-grade siliceous ores of the Lake District, of both of which there are enormous quantities.

\section{BraziL.}

One of the greatest ore reserves of the world, and certainly the greatest reserve of ore suitable for the acid Bessemer process, is situated in the province of Minas Geraes, in Brazil.

The ores are hæmatite and magnetite, and occur in rocks similar to the banded jasper of North America and South Africa. They vary in grade, but the average iron content is over 60 per cent, and the phosphorus is in the main well below the Bessemer limit. A proportion of the ore occurs in thin lamellæ between siliceous layers, but there are large masses of practically pure oxide, like that of Iron Ore Peak (Itabira do Campo) and the Caué deposit of Itabira do Matto Dentro, which is estimated to contain 80 million tons of the highest quality ore. F. C. Harder states that the largest deposit contains at least 350 million tons, and that there are numerous ore-bodies of from 10 to 50 million tons. Their possible aggregate tonnage is enormous, but with the present means of transportation the greater portion is inaccessible. Before the War capital was being found to develop these fields and to provide transportation, and it cannot be long before such valuable deposits will be utilized in the world's markets. The ore will probably be exported in great quantity to British and American Bessemer furnaces.

The economically important ores of Minas Geraes are usually divided into (a) Bedded or Quarry Ores, consisting of (1) thick bedded massive hematite, and (2) thinly bedded siliceous hematita ("jacutinga"); (b) Fragmental Ores, consisting of (1) rubble ore (a denudation product of the bedded ores), and (2) Canga (recemented rubble).

The massive ore beds vary in thickness from less than a foot to more than 300 feet, but they are less extensive than the jacutinga ores. Leith and Harder state that single lenses of jacutinga are known more than 3 miles in length and up to 2,000 feet in thickness. Of the high grade massive hæmatite and jacutinga, ranging in iron content from 63 to 69 per cent, the tonnage was stated by Leith, in 1911 , to be probably not far short of the total reserves of the Lake Superior district available at that date. The Canga and rubble ores are of lower grade; even these probably average 50 per cent in iron, but the phosphorus is higher than in the bedded ores.

Estimates of the total available reserves in the Minas Geraes field vary from the conservative estimate of 2,000 million tons made by Dr. Derby for the Stockholm Report, up to recent estimates of 3,500 millions. For the whole iron ore region of Brazil, Merriam 
and Leith estimate the potential reserves at 7,500 million tons of ore; while Mineral Industry (1918) credits Brazil with 5,000 million tons of 63 per cent grade. With regard to the phosphorus content it must be borne in mind that while the quantity of Bessemer ore is very great, in all probability exploration will show that a proportion of the ore is above the Bessemer limit.

\section{Cuba.}

The Stockholm estimate for Cuba was 1,903 million tons. More recent estimates agree in placing the reserves at from 2,500 to 3,000 million tons of crude ore ( 36 per cent iron) for the lateritic blanket deposits of the north coast. There are three distinct orefields, namely, those of the districts of Mayari, Moa, and Levisa, of which Mayari is the only one worked at present. The soft, clayey ore is removed by mechanical excavators to an average depth of 19 feet, and there is no overburden. Since it contains from 20 to 30 per cent of moisture, and about 13 per cent of combined water, it is calcined in nodulizing kilns before being shipped to Sparrows Point and Steelton, in the United States, losing thereby one-third of its weight. According to Weld, the nodulized ore averages 55 per cent iron, 450 per cent silica, 13 per cent alumina, 1 per cent nickel, and 2 per cent chromium; phosphorus is below the Bessemer limit, and sulphur is negligible. Mixed with other iron, the pig produced from these ores is used for making chilled castings; but the bulk of it goes to make steel for rails, truck-bolts, and all sorts of motor-car parts. The steel is stated to contain from 1 to 1.5 per cent of nickel, and from 0.2 to 0.7 per cent of chromium, with sulphur and phosphorus below 0.04 per cent.

\section{NEWFOUNDLAND.}

No exact estimate of the iron resources of Newfoundland is possible, since, with the exception of a small area where the ore beds outcrop on Bell Island, the whole of this field is under Conception Bay. The ore is a dense bedded hæmatite, averaging over 50 per cent iron, 0.8 per cent phosphorus, and about 10 per cent silica, and therefore suited for the basic process. It occurs in three workable beds of an aggregate thickness of 30 feet, in a trough of Ordovician rocks, which, dipping at a low angle from the outcrop on Bell Island, passes under the sea.

The Wabana mines on Bell Island are operated by the Nova Scotia Iron and Coal Co. and the Dominion Iron and Steel Co., the former company working the upper beds and the latter company the lower bed. The combined output averages about 700,000 tons per annum. The Nova Scotia Co. has recently completed two inclined shafts, by means of which 12,000 tons a day is being raised from workings 2 miles to the dip under the sea. The whole enterprise has recently been merged in the Empire Steel Corporation, in which both British and Canadian capital participate. 


\section{F. H. Hatch-The Iron Ore Sxpplies of the World.}

The amount of ore ultimately to be recoverable will depend on the engineering skill that can be brought to bear on the problems of ventilation and pumping that such extensive submarine mining will present. E. C. Eckel estimates the economically workable ore at 3,500 million tons of 50 per cent ore within a radius of 5 miles of Bell Island. Newfoundland was credited with 3,635 million tons in the Stockholm Report.

\section{Canada.}

Very little is known regarding the iron resources of the Dominion. Of the $1 \frac{3}{4}$ million tons of iron-ore smelted in Canadian blast-furnaces in 1919 , only 5 per cent was of domestic origin, the balance coming from Lake Superior mines in the United States and from the Wabana mines of Newfoundland. The domestic ores are sedimentary hæmatite ores from Nova Scotia, magnetite from New Brunswick, Eastern Ontario, Quebec, and Texada Island, in British Columbia, and spathic ore from the Michipicoten district of Ontario. The carbonate ore at the Magpie mine, worked by the Algoma Steel Corporation in the latter district, averages 34 per cent iron for the raw stone, and 50 per cent for the calcined material. The low-grade magnetite deposits worked by the Moose Mountain Company at Sellwood, in Ontario, average 34 per cent iron, but the briquetted concentrates run as high as 63 per cent.

The total reserves of the Dominion have been estimated at only 150 million tons, but with the vast unexplored country in Northern Canada it is hard to believe that big reserves will not some day be discovered.

\section{South AND West AFrica.}

Iron-ore of various types are known to exist in South and West Africa. Lateritic deposits similar to those of Cuba, and characterized by a rather high silica and alumina content and small percentages of nickel, chronium, manganese, ete, are common in many parts of the country. One in French West Africa has recently been found to have a reserve of 100 million tons, and to yield a nodulized product running over 60 per cent iron. Hæmatite-magnetite deposits associated with Pre-Cambrian rocks occur over large areas; but they are generally too interlaminated with siliceous material to be workable. This type, however, is stated to be of economic importance in Rhodesia. In the Transvaal there are extensive deposits of low-grade phosphoric ores in the Pretoria Beds, near Pretoria, and at Boskop, near Potchefstroom, which can be used as mixing ores; but the most valuable deposit yet discovered is a high-grade low-phosphorus hæmatite with over 60 per cent iron, occurring at Kromdraai, 45 miles north-east of Pretoria, which it is proposed to mix with the lower-grade phosphoric ores of Boskop for the manufacture of basic pig at Vereeniging.

With the existing data no estimate as to reserves can be made, but it appears certain that large tonnages of iron-ore are available 
in the Transvaal, from which suitable mixtures for smelting to basic pig can be made.

\section{INDIA.}

The following particulars with regard to India are taken from a note kindly prepared for me by Dr. Coggin Brown, of the Indian Geological Survey.

Important deposits of high-grade iron-ore, mainly hæmatite, associated with banded jasper, and in this respect similar to those of Lake Superior and Brazil, have recently been opened up in India. The best-known deposits are those of Mayurbhanj and Singhbhum, in Bihar and Orissa; Chanda and Drug in the Central Provinces; Kadur in Mysore; and Goa. The Mayurbhanj deposits are being worked by the Tata Iron and Steel Company at Gurumaishini, where a lens of hæmatite has been proved to contain 15 million tons for every 10 feet of depth. This ore averages over 60 per cent iron, manganese $0 \cdot 8$, sulphur $0 \cdot 01$, and phosphorus $0 \cdot 09$. The basic pig made from this ore at the Tata Ironworks, which are situated within 40 miles of the mine workings, contains about 0.04 per cent phosphorus, under 0.05 sulphur, and less than 1 per cent silicon. Similar ore bodies are known at Okampad and Badampahar.

The Singhbhum deposit is being worked at Pansira Hill and Budu Hill, south-east of Manharpur, on the Bengal-Nagpur Railway. It appears to be a part of an iron-ore range forming a definite horizon in the Dharwar rocks, and extending for some 40 miles in a southwesterly direction from Singhbhum. Enormous quantities of ore are believed to exist, but until the supposed extensions have been definitely proved in depth by drilling, no estimate as to quantity can be made.

In the Chanda and Drug districts of the Central Provinces, deposits of high-grade low-phosphorus ore have been discovered, but have as yet not been extensively prospected. The Mysore ores are not of great extent. They are being worked tentatively by the Tata Iron and Steel Company, for the Mysore Government. Highgrade low-phosphorus ores exist in Goa and Ratnagiri, probably in considerable quantity; but they have not as yet been proved in depth.

Altogether the reserves of high-grade ore already partly proved in India may be safely put at several hundred million tons, and the prospects are favourable for the existence of very much larger quantities.

\section{Australia.}

Little is known of the iron-ore resources of Australia except that many important deposits exist both near the coast and in the interior. Some of these are at present being investigated in South Australia, Western Australia, Queensland, and Victoria.

A high-grade ore is being worked in South Australia by the Broken Hill Proprietary Company at Iron Knob. The ore is carried 


\section{F. H. Hatch-The Iron Ore Supplies of the World.}

at low cost by water transportation to the Company's ironworks at Port Waratah near Neweastle in New South Wales, where it is smelted to basic pig for open-hearth steel manufacture. Work at Iron Knob is at present restricted to quarrying, and the output is about 300,000 tons per annum. No figures as to reserves are available.

\section{Conclusions.}

Summarizing the estimates for the great ore-fields of Europe and the Americas (namely, the United States, Cuba, Newfoundland, Brazil, Scandinavia, Central Europe, the United Kingdom, Spain, and North Africa) we arrive at the following round figures:--

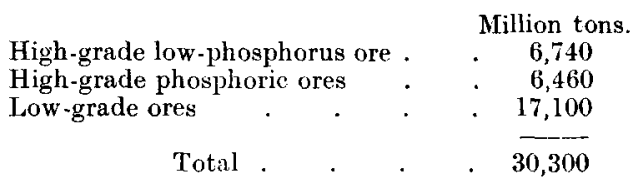

Another 1,500 million should be added for the small ore-fields of Russia, Austria, and Greece in Europe, and Chile, Venezuela, Mexico, and Canada in America, making a grand total for the two continents of 31,800 million tons, of which the equivalent iron is 14,310 million tons, or, on the basis of a pig-iron production of 70 million tons a year, sufficient to last over 200 years.

The resources of the continents of Africa, Asia, and Australia are unknown, but it has been shown in the foregoing that important deposits exist in South Africa, Australia, and India, and others are known, for instance, in China, Korea, and Japan. Moreover, having regard to the very large unexplored areas of these continents the existence of great reserves as yet undiscovered is very probable.

An ingenious method suggested by Sjögren and used by Eckel enables the iron-ore resources of the unknown continents of Africa, Asia, and Australia to be roughly estimated on the basis of the known resources of Europe and America. It is assumed that the resources of these countries are likely to be in some proportion to the areas, which, as the geological principles involved are the same in both cases, is not too unreasonable an assumption for the purpose in view. The ton-mile factor for the known continents works out at 1,646 tons per square mile. Applying this to the areas of the unknown continents we get a figure of 52,200 million tons for the reserves, which, added to the figure already obtained for Europe and America, gives a grand total of 84,000 million tons for the world's resources of commercial ore, in the sense of the presentday usage of the term.

On the whole adequate iron-ore supplies for the chief smelting centres of the world seem reasonably secure for a remote future. One fact, important for the makers of hæmatite steel, clearly emerges, and that is the relative scarcity of low-phosphorus ore. Excepting the great reserve of the very highest quality ore in Brazil the known 
reserves of low-phosphorus ore in the rest of the world only amount to some 1,740 million tons, the bulk of which is in the United States. The European resources of this class of ore are small and rapidly diminishing, and the claims on them are increasing. Spain is engaged in the development of a new iron and steel industry, and France will require a larger proportion of the North African ore. The British ironmaster, if he is to continue making hæmatite steel, will sooner or later be driven to seek his ore supplies outside Europe, and that indicates Brazil as the future main source of this class of ore. 